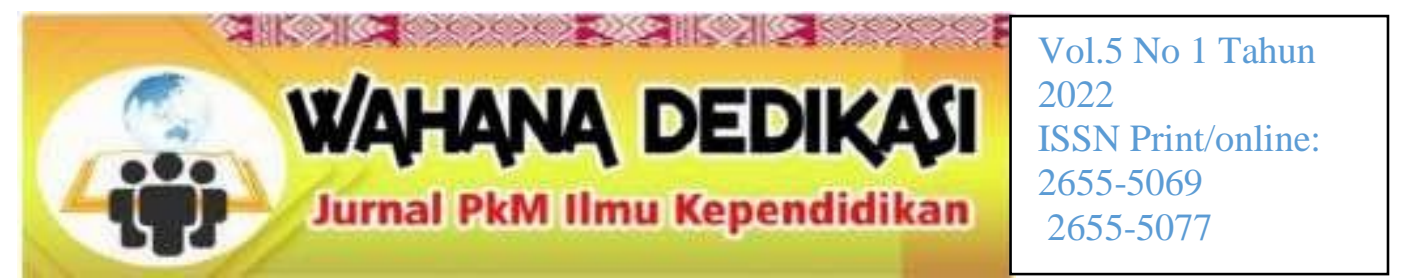

\title{
PROGRAM PEMBUATAN VIRGIN COCONUT OIL (VCO) DI DESA MUARA PENIMBUNG ILIR SEBAGAI PEMBERDAYAAN MASYARAKAT
}

\author{
Dwirini $^{1}$, Relasari ${ }^{2}$, Abukosim $^{3}$, Meita Rahmawati ${ }^{4}$, Ruth Samantha ${ }^{5}$ \\ Program Studi Akuntansi Universitas Sriwijaya ${ }^{1,2,3,4}$ \\ dwirini@unsri.ac.id ${ }^{l}$,relasari_mkr@yahoo.co.id ${ }^{2}$,abukosim@unsri.ac.id ${ }^{3}$, \\ meita_1386@yahoo.com ${ }^{4}$,ruth_shasa@yahoo.com ${ }^{4}$
}

\begin{abstract}
Abstrak
Pemberdayaan berasal dari kata "daya" yang mendapat awalan ber menjadi kata "berdaya" artinya memiliki atau mempunyai daya/kuat. Kata "pemberdayaan" dalam terjemahan bahasa inggris adalah "Empowerment", yang berasal dari kata "power" yang berarti kekuatan berbuat, mencapai, melakukan atau memungkinkan. Awalan "em" dapat berarti kekuatan dalam diri manusia, suatu sumber kreativitas. Pemberdayaan masyarakat merujuk pada kemampuan orang khususnya kelompok rentan dan lemah sehingga mereka memiki kekuatan/kemampuan dalam menciptakan alternatif tindakan ekonomi. Tujuan dari kegiatan pengabdian ini adalah dapat mendorong dan memberikan dampak ekonomi, termasuk keterlibatan masyarakat pada program pembuatan Virgin Coconut Oil (VCO) dengan cara mengelola kelapa menjadi minyak murni. Hasil pengabdian masyarakat ini yaitu peningkatan pengetahuan, pemahaman dan pemanfaatan minyak kelapa murni atau VCO.
\end{abstract}

Kata kunci: Pemberdayaan Masyarakat, Covid-19, Pendapatan, Virgin Coconut Oil (VCO)

\begin{abstract}
Empowerment comes from the word "power" which gets the prefix "em" to become the word "empowered" which means having or having power/strong. The word "empowerment" in the English translation is "Empowerment", which comes from the word "power" which means the power to do, achieve, perform or enable. The prefix "em" can mean the power in humans, a source of creativity. Community empowerment refers to the ability of people, especially vulnerable and weak groups so that they have the strength/ability to create alternative economic actions. The purpose of this service activity is to encourage and have an economic impact, including community involvement in the Virgin Coconut Oil ( $\mathrm{VCO}$ ) production program by managing coconut into pure oil. The result of this community service is an increase in knowledge, understanding and utilization of virgin coconut oil or VCO.
\end{abstract}

Keywords: Community Empowerment, Covid-19, Income, Virgin Coconut Oil (VCO)

Artikel Diterima : 28-11-2021 Artikel disetujui tanggal:04-01-2022 Artikel Diterbitkan :16-01-2022

Corresponden Author:Dwirini e-mail:dwirini@unsri.ac.id

DOI: $\underline{\text { http://dx.doi.org/10.31851/dedikasi.v5i1.6692 }}$

\section{PENDAHULUAN}

Indonesia begitu kaya akan sumber daya alam yang dimiliki salah satunya adalah komoditas kelapa. Dengan luas lahan tanaman Kelapa 3,439 juta hektar menjadikan Indonesia sebagai negara yang memiliki lahan tanaman kelapa terluas di dunia. Hal ini dapat diartikan bahwa perlu adanya pengelolaan yang baik terhadap komoditas kelapa sebagai salah satu penunjang ekonomi masyarakat di Indonesia agar komoditas ini dapat terus berkembang sesuai dengan kebutuhan dan permintaan akan produksi kelapa. Rata-rata pemilik lahan perkebunan kelapa adalah 


\section{WAHANA DEDIKASI}

masyarakat perdesaan dengan demikian perlu adanya dukungan dalam pengembangan dan pemberdayaan komoditas kelapa.

Provinsi Sumatera Selatan menghadapi dampak ekonomi akibat virus corona yang berasal dari Wuhan, China dan merebak ke banyak negara, banyak daerah-daerah masih tergantung pada ekspor komoditas seperti karet dan kelapa sawit yang mengalami penurunan harga. Hampir $67 \%$ masyarakat Indonesia mengalami kondisi ekonomi yang makin memburuk sejak pandemi Covid-19. Sebanyak 92\% masyarakat juga menganggap Covid19 mengancam nyawa manusia, sehingga ada kekhawatiran antardaerah, juga masyarakat daerah sekitar Sumatera Selatan. Minggu kedua Juni 2021 daerah sekitar di Sumatera Selatan berada di zona merah karena berisiko tinggi penularan virus Covid-19.

Tepat 17 Maret 2020, awal mula Covid-19 masuk ke Indonesia, selama hampir setahun terakhir pemerintah meringankan beban ekonomi masyarakat yang terkena pandemi mulai dari pengangguran, para usaha mikro, kecil, menengah (UMKM), karyawan swasta, aparatur sipil Negara (ASN), dan juga murid dan mahasiswa. Kondisi tersebut memicu pemerintah untuk memberikan bantuan selama enam bulan di masa pandemi. Dampak bantuan yang terjadi di Desa Muara Penimbung dapat meningkatkan daya beli yang terus tumbuh.

Adapun kebijakan yang dikeluarkan oleh pemerintah pada masa pandemi adalah membantu perekonomian masyarakat yang terdampak pandemi Covid-19 dengan cara mengganti mekanisme pengalokasian dana desa dimasa pandemi.. Tujuan kebijakan ini agar dapat memberdayakan masyarakat yang terdampak dan menstabilkan perekonomian masyarakat di desa akibat pandemi virus corona ini. (Permendes Nomor 6 Tahun 2020).

Desa Muara Penimbung Ilir terletak di Kecamatan Indralaya Utara Kabupaten Ogan Ilir Provinsi Sumatera Selatan. Kabupaten Ogan Ilir memiliki 16 kecamatan, diantaranya Kecamatan Indralaya Utara dengan luas 473,33 km2, yang memilki 15 desa, 1 kelurahan dan jumlah penduduk pada tahun 2017 sebanyak 34.902 jiwa.

Wilayah bawahan yang ada di Desa Muara Penimbung Ilir ini terdapat 12 Rukun Tetangga (RT) yang tergabung dalam 6 dusun, masing-masing dusun dipimpin oleh satu kepala dusun (Kadus). Luas pemukiman warga mencapai luas 380 Ha dimana 120 Ha didalamnya merupakan lahan pekarangan yang sebagian besar tidak dimanfaatkan (lahan kosong).

Jumlah penduduk Desa Muara Penimbung pada tahun 2020 adalah 1.428 jiwa, terdiri dari 735 laki-laki dan 747 perempuan dan jumlah rumah tangga sebanyak 408 rumah tangga, dengan luas wilayah $621 \mathrm{Ha}$ yang mencakup $135 \mathrm{Ha}$ tanah sawah, $380 \mathrm{Ha}$ tanah darat dan $106 \mathrm{Ha}$ Perairan. Penduduk Muara Penimbung termasuk orang pegagan yang daerah kawasannya terdiri atas tiga suku yaitu Pegagan Ilir Suku Satu (PSS I), Pegagan Ilir Suku Dua (PSS II), dan Pegagan Ilir Suku Tiga(PSS 


\section{W/AHANA DEDIKASI}

III).

Pada masa Pasirah Ruslan Muara Penimbung termasuk Pegagan Ilir Suku Tiga(PSS III) yang daerah kawasannya adalah (a) Muara Penimbung (Muara Penimbung Ulu, Muara Penimbung Ilir); (b) Talang Aur (Talang Aur dan Tunas Aur); (c) Ulak Banding, dan (d) Muara Kamal (Penyandingan, Sudimampir). Pada tahun 2005 desa Muara Penimbung terjadi pemekaran yaitu desa Muara Penimbung Ulu dan desa Muara Penimbung Ilir.

Desa Muara Penimbung Ilir mempunyai iklim kemarau dan penghujan sebagaimana desa-desalain di wilayah Indonesia dalam hal tersebut mempunyai pengaruh langsung terhadap pola tanam yang ada di desa Muara Penimbung, Kecamatan Indralaya Utara. Variasi atau ragam karakteristik desa terdiri dari kekayaan alam desa, sumberdaya manusia yang ada, jenis mata pencaharian dan lain sebagainya. Mayoritas penduduknya bermatapencaharian sebagai petani, pengrajin serindak (topi/ caping yang digunakan untuk bertani), peternakan kemudian diikuti buruh harian lepas (buruh bangunan), PNS dan pengelola budaya ikan.

Semua orang ikut merasakan dampak dari adanya pandemi Covid19, pemerintah telah menerapkan program pshysical distancing supaya masyarakat tidak membuat kerumunan. Pemerintah juga menghimbau masyarakatnya untuk melakukan semua kesibukannya di rumah saja, seperti halnya bekerja, belajar dan beribadah. Salah satu dampak dari pandemi ini adalah kegiatan yang awalnya produktif untuk dilakukan di luar rumah, sekarang dipindah di dalam rumah. Karena ada keterbatasan ruang gerak warga, maka kami dari Tim Pengabdian UNSRI ingin melakukan kegiatan pengabdian bersifat sosialisasi pengetahuan baru tentang pengelolaan kepala sebagai minyak murni dan memiliki banyak khasiat kesehatan kita. Minyak murni tersebut dikelola dari buah kelapa yang biasa disebut dengan Virgin Coconut Oil (VCO).

Pandemi Covid-19 berdampak langsung terhadap pendapatan masyarakat di Desa Muara Penimbung Ilir. Perbandingan tiga dari 10 masyarakat mengakui bahwa pendapatan mereka berkurang lebih dari 50 persen dibanding sebelum pandemi ini. Bagi para rumah tangga di Desa Muara Penimbung, ada beberapa kegiatan yang dapat dimanfaatkan di era pandemi yaitu dengan cara melakukan hal-hal yang kita suka dan merujuk kepada kegiatan yang bersifat santai dan menyenangkan, seperti mengelola kelapa menjadi minyak murni.

Jika masyarakat mampu mengolah kelapa beserta limbahnya dengan baik maka akan sangat mungkin penghasilan yang diperoleh oleh masyarakat akan meningkat seiring dengan pengolahan yang baik. Kelapa dapat diolah kedalam bentuk lain yaitu Virgin Coconut Oil (VCO) karena banyak manfaat yang terkandung didalamnya, VCO memiliki kemampuan sebagai antivirus, antibakteri, antijamur, antiprotozoa, dan antioksidan, serta kemampuan untuk meningkatkan jumlah sel darah putih.

Penghasilan adalah uang yang diterima dan diberikan kepada subjek 


\section{WAHANA DEDIKASI}

ekonomi berdasarkan prestasi-prestasi yang diserahkan yaitu berupa pendapatan dari profesi yang dilakukan sendiri atau usaha perseorangan dan pendapatan dari kekayaan (Sumitro, 1990). Mulyadi (2008) mengatakan penghasilan atau disebut pendapatan adalah jumlah seluruh penghasilan atau penerimaan yang diperoleh baik berupa gaji atau upah maupun pendapatan dari usaha dan pendapatan lainnya selama satu bulan.

Kreativitas rumah tangga penting di Desa Muara Penimbung

Ilir agar dapat bertahan dari sisi ekonomi di masa pandemi Covid-19. Kreativitas dapat menghasilkan pendapatan atau penghasilan keluarga dalam memenuh kebutuhan keluarga. Dengan adanya pengetahuan baru tentang cara mengelola kelapa beserta limbahnya, maka masyarakat di Desa Muara Penimbung Ilir dituntut untuk mengaplikasikan proses pembuatan kelapa menjadi minyak murni di rumah saja khususnya di era pandemi.

Dengan membuat minyak kelapa sendiri dapat memperoleh keuntungan bagi keuangan rumah tangga dan beragam manfaat bagi kesehatan tubuh. Minyak kelapa memiliki beragam kandungan yang baik untuk kesehatan, seperti asam urat dan lemak jenuh yang disebut medium chain triglycerides (MCT). Jenis lemak tersebut dapat digunakan oleh hati untuk menghasilkan energi bagi tubuh.

Pelaksanaan dalam proposal ini adalah berupa pelatihan pembuatan Virgin Coconut Oil (VCO) Di Desa Muara Penimbung Ilir sebagai pemberdayaan masyarakat guna menciptakan kreativitas bagi kehidupan ekonomi keluarga dan membantu menghadapi tantangan hidup ekonomi yang berat di masa pandemi Covid-19.

Untuk memahamipermasalahan keuangan rumah tangga yang sedang dalam masa penuh tantangan maka menuntut prioritas akan kesehatan, kebersihan pribadi dan keluarga dan juga tantangan finansial tersendiri, maka kami Tim Pengabdian UNSRI memberikan solusi positif untuk membantu kelompok masyarakat di Desa Muara Penimbung Ilir melalui pemberdayaan (Empowerment) dengan mengelola kelapa menjadi minyak murni. Pengelolaan minyak kelapa ini bisa dilakukan di rumah saja dan terjamin keasliannya sehingga manfaat dari minyak kelapa dapat dihasilkan secara optimal.

Tujuan pelatihan ini khususnya adalah dalam hal-hal sebagai berikut:

a. Peserta mampu membuat virgin coconut oil (VCO)

b. Peserta mampu dan terampil mengaplikasikan virgin coconut oil (VCO) di rumahnya dengan baik dan aman.

c. Peserta mampu dan terampil memperkenalkan virgin coconut oil (VCO) dan manfaatnya kepada kerabat keluarga

\section{BAHAN DAN METODE}

Bahan dan metode pelaksanaan kegiatan pengabdian ini tim kami laksanakan dengan rincian sebagai berikut:

\section{Bahan Kegiatan}

Adapun bahan kegiatan program pembuatan virgin coconut oil (VCO) di Desa Muara Penimbung 
Dwirini $^{1}$, Relasari $^{2}$, Abukosim $^{3}$, Meita Rahmawati ${ }^{4}$, Ruth Samantha ${ }^{5}$

Program Pembuatan Virgin Coconut Oil (VCO) Di Desa Muara Penimbung Ilir Sebagai Pemberdayaan Masyarakat

\section{WAHANA DEDIKASI}

Ilir bagi kelompok masyarakat antara

lain:

5 | Wahana Dedikasi

Copyright@Dwirini 


\section{WAHANA DEDIKASI}

1. Pencatatan bahan-bahan dan alat-alat yang digunakan untuk mengelola virgin coconut oil (VCO) khususnya kelapa.

2. Cara bagaimana membuat virgin coconut oil (VCO) melalui kelapa diubah menjadi minyak murni pada kelompok masyarakat di Desa Muara Penimbung Ilir.

3. Memberikan bekal terkait manfaat-manfaat yang diperoleh dari membuat virgin coconut oil (VCO) secara aman pada kelompok masyarakat di Desa Muara Penimbung Ilir.

\section{Metode Pelaksanaan}

Pelaksanaan kegiatan pengabdian pada masyarakat ini dilakukan dengan menggunakan metode ceramah, tutorial, dan diskusi. Adapun sistematika pelaksanaan kegiatan pengabdian ini adalah sebagai berikut:

a) Langkah pertama (Metode Ceramah): Peserta diberikan motivasi agar memiliki kemauan dan berkreativitas untuk membuat virgin coconut oil (VCO). Selain itu, peserta diberikan materi gambaran umum tentang proses pembuatan VCO dari bahan utama yaitu kelapa. Langkah pertama diselenggarakan selama 30 menit. b) Langkah kedua (Metode Tutorial): Peserta pelatihan diberikan pengaplikasian secara langsung mulai dari penyediaan bahan-bahan dan alat-alat yang dibutuhkan sampai dengan produk akhirnya VCO. Langkah kedua diselenggarakan selama 1 jam.

c) Langkah ketiga (Metode Dialog): Peserta pelatihan diberikan kesempatan untuk mendiskusikan permasalahan yang berkaitan dengan program pembuatan VCO dihadapi dan memberikan solusi. Langkah ketiga diselenggarakan selama 30 menit.

Materi kegiatan pengabdian masyarakat ini bagi kelompok masyarakat diharapkan dapat memberikan pengetahuan baru pada tataran konsep dan tataran praktik.

Tataran konsep diharapkan mampu memberikan pemahaman konsep pemberdayaan masyarakat (Empowerment) melalui pengelolaan kelapa menjadi minyak murni (VCO) bagi peserta dalam hal ini kelompok masyarakat di Desa Muara Penimbung. Konseptual empowerment memberikan pemahaman positif di mana kesadaran kritis masyarakat dibangun dan dikembangkan sehingga masyarakat dapat menjadi produsen bagi dirinya sendiri.

Tataran praktik memberikan pemahaman kepada kelompok masyarakat mengenai proses 


\section{WAHANA DEDIKASI}

pembuatan VCO terkait materi pelatihan. Materi pelatihan mengenai proses pembuatan dan pengaplikasian secara langsung dari kelapa menjadi minyak murni pada masyarakat di Desa Muara Penimbung Ilir.

\section{HASIL DAN PEMBAHASAN}

Tahap pertama, pembukaan dan perkenalan dengan masyarakat desa Muara Penimbung Ilir yang merupakan khalayak sasaran. Pserta pelatihan diberikan motivasi agar memiliki kemauan dan berkreativitas untuk membuat virgin coconut oil (VCO).

Tahap kedua, metode Tutorial dengan cara peserta pelatihan diberikan pengaplikasian secara langsung mulai dari penyediaan bahan-bahan dan alat-alat yang dibutuhkan sampai dengan produk akhirnya VCO. Selain itu, peserta juga diberikan materi gambaran umum tentang proses pembuatan VCO dari bahan utama yaitu kelapa.

Tahap ketiga, metode Dialog dengan cara peserta pelatihan diberikan kesempatan untuk berdiskusi/ tanya jawab mengenai permasalahan proses pembuatan VCO yang dihadapi dan memberikan solusi.

Tahap terakhir, penutupan oleh moderator (Tim Pengabdian) dengan melakukan dokumentasi berupa foto bersama dengan peserta pelatihan dan Kepala Desa.

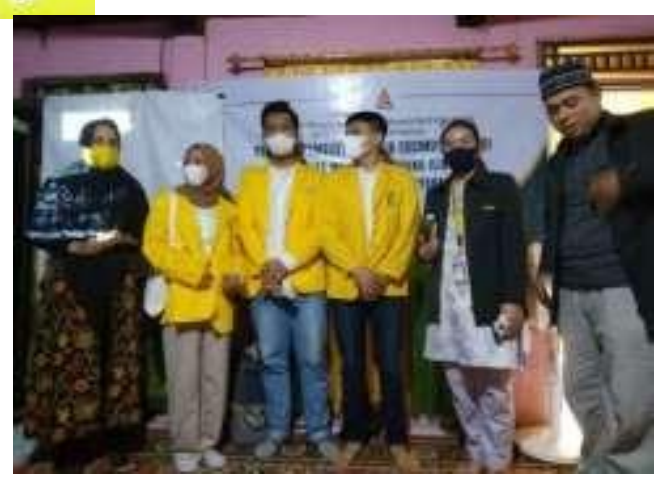

Gambar 1. Kata Sambutan dari Tim pengabdian

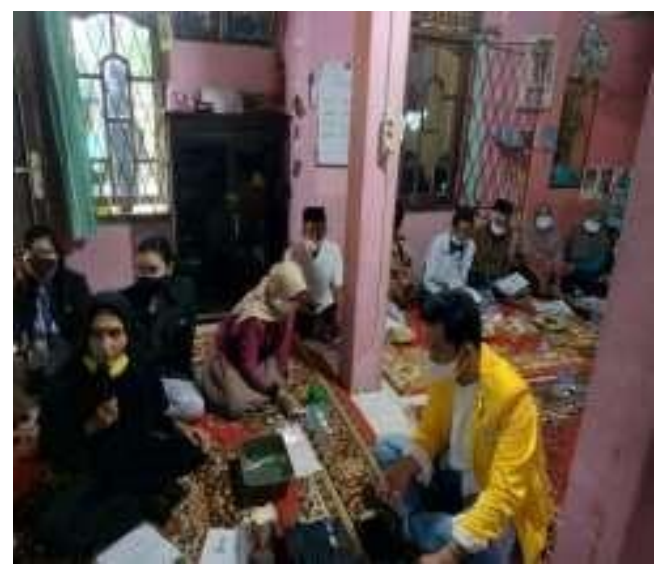

Gambar 2. Penyampaian Isi Materi oleh Narasumber

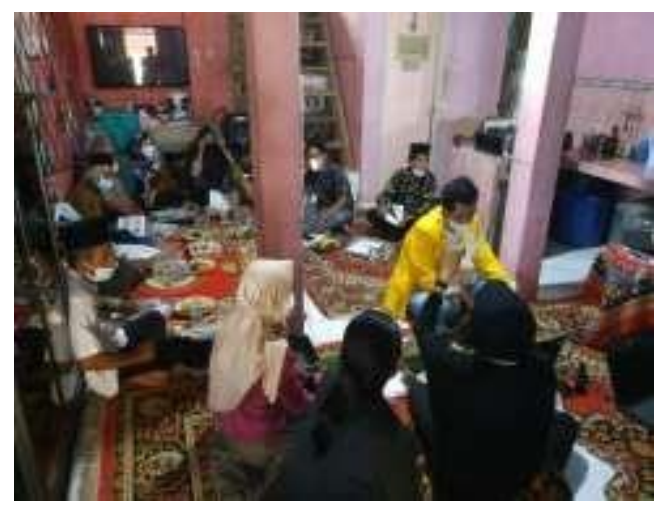

Gambar 3. Para peserta pelatihan menyimak isi materi 


\section{WAHANA DEDIKASI}

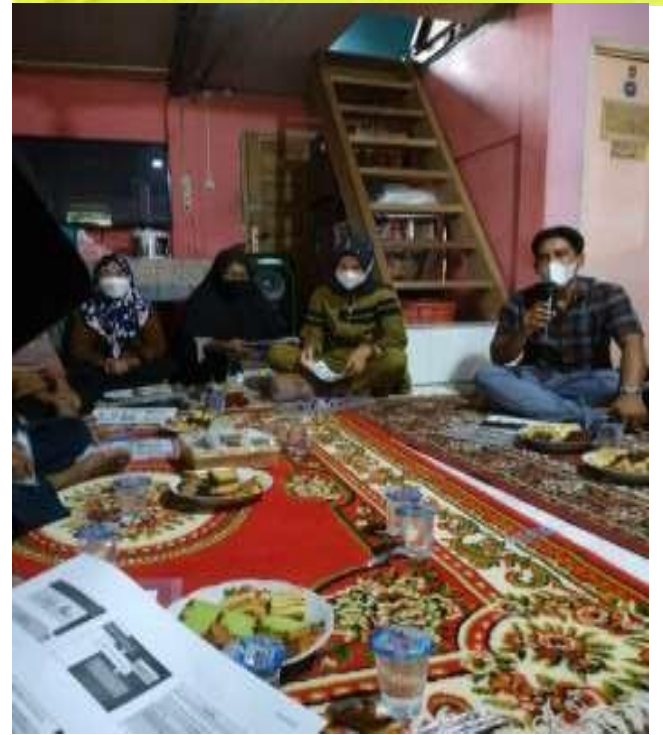

Gambar 4. Salah satu peserta berdialog

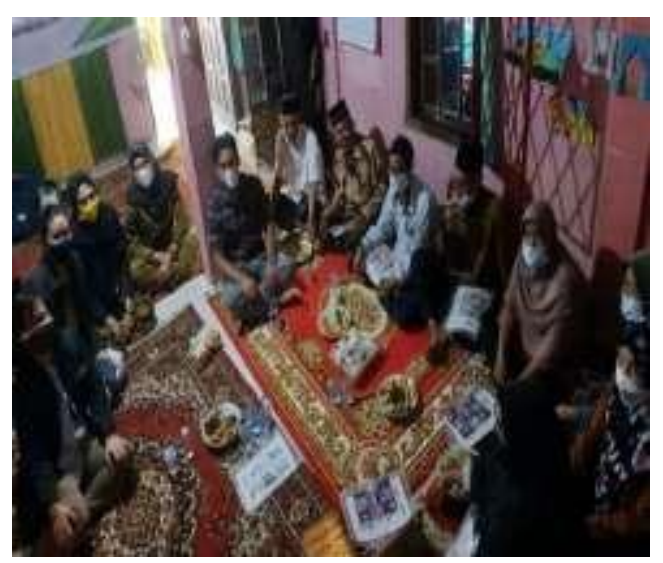

Gambar 5. Salah satu peserta berdialog

Sebelum melakukan kegiatan pelatihan, para peserta dan tim pengabdian telah menerapkan protokol kesehatan. Langkah pertama, narasumber memberikan gambaran umum tentang proses pembuatan VCO dari bahan utama yaitu kelapa (diselenggarakan selama 1 jam). Narasumber mulai mempresentasikan materi pelatihan mengenai pengertian Virgin Coconut Oil (VCO), dampak masa pandemi terhadap kondisi ekonomi keluarga yang tidak stabil, karena ada keterbatasan ruang gerak warga, maka kami dari tim pengabdian melakukan sosialisasi dengan cara memanfaatkan bahan alam yaitu kelapa tua yang akan diolah menjadi minyak murni disebut virgin coconut oil (VCO) dan memiliki khasiat kesehatan, salah satunya membantu pencernaan dan membantu meningkatkan imunitas tubuh. Selama kegiatan pelatihan berlangsung peserta sangat antusias dan memperhatikan isi materi pelatihan.

Kegiatan pelatihan dan pengaplikasian proses pembuatan VCO berlangsung selama 60 menit dan di akhir sesi pemateri memberikan kesempatan kepada peserta untuk mengajukan pertanyaan terkait materi dan pengaplikasian yang telah disampaikan. Didapatkan 3 pertanyaan dari peserta pelatihan terkait isi materi. Setelah menjawab pertanyaan dari peserta, narasumber melakukan evaluasi terkait proses pembuatan VCO secara higienis dengan cara memberikan pertanyaan dan memberikan kesempatan kepada peserta lain untuk menjawab pertanyaan tersebut. Kegiatan pelatihan ini ditutup dengan kegiatan foto bersama antara narasumber dengan peserta pelatihan.

Sesi diskusi yang didapat dari kegiatan pengabdian masyarakat ini diantaranya adalah:

1. Peserta diberikan beberapa bekal terkait manfaat-manfaat yang diperoleh dari membuat VCO secara higienis dan aman pada kelompok masyarakat di Desa Muara Penimbung Ilir.

2. Dari hasil pelatihan, peserta memahami mengenai isi materi dan proses pembuatan 


\section{W/AHANA DEDIKASI}

VCO dan di akhir sesi diberikan waktu diskusi/ tanya jawab. Didapatkan beberapa pertanyaan dari peserta pelatihan yaitu:

a) Bagaimana cara terbaik menggunakan VCO?

Solusinya: banyak cara menggunakan VCO, salah satunya dapat meminumnya per sendok per hari. Serta dapat dijadikan lotion alami yang berkhasiat untuk menyembuhkan dan melindungi kulit.

b) Apakah VCO bisa digunakan sebagai pengganti minyak goreng? Solusinya: VCO berasal dari minyak murni, dapat juga memasak dengan menggunakan $\mathrm{VCO}$, terutama untuk diet.

c) Apakah VCO mengandung kolesterol yang tinggi? Solusinya: VCO adalah berasal dari kelapa yang berusia tua dan diolah dengan metode fermentasi menghasilkan minyak murni atau minyak sayur dan karena itu tidak mengandung kolesterol. Kolesterol hanya ditemukan pada lemak hewani dan susu.

\section{KESIMPULAN}

1. Kegiatan pengabdian kepada masyarakat mengenai proses pembuatan dan pengaplikasian VCO secara langsung dari kelapa menjadi minyak murni yang baik dan aman di desa Muara Penimbung yang berjalan secara langsung dengan lancar dan menerapkan protokol kesehatan.

2. Kegiatan pengabdian kepada masyarakat mengenai proses pembuatan VCO dengan model pelatihan dan pendampingan di Desa Muara Penimbung Ilir mendapatkan respon yang antusias dari para peserta pelatihan yang berjumlah 26 orang.

3. Diperoleh 3 pertanyaan dari peserta pelatihan (kelompok masyarakat) terkait materi dan proses pembuatan VCO ini serta peserta pelatihan mengharapkan ada kegiatan rutin setiap tahun ada kegiatan pengabdian kembali terkait menghitung harga pokok produksi.

\section{DAFTAR PUSTAKA}

Djojohadikusumo, Sumitro. 1990.
Sejarah
Pemikiran
Ekonomi.
Jakarta :
Yayasan Obor Indonesia.

Edi, Suharto. 2005. Membangun Masyarakat

Memberdayakan Rakyat Kajian Strategis Pembangunan

Kesejahteraan Sosial Dan Pekerja Sosial. Bandung: PT Revika Aditam.

Hammer, Lawrence H. Carter, and Usry. 2004. Akuntansi Biaya (Jilid 1 dan 2). Jakarta: Salemba Empat.

Mardiasmo. 2008. Ekonomi Sumber Daya Manusia. Jakarta: Raja Grafindo Persada. 


\section{WAHANA DEDIKASI}

Mardikanto, Totok dan Soebiato,

Poerwoko. 2015.

Pemberdayaan Masyarakat.

Bandung: Alfabeta.

Mulyadi. 2000. Akuntansi Keuangan

Dasar. Edisi Kedua.

Yogyakarta: BPFE.

Mulyadi. 2010. Sistem Akuntansi.

Jakarta: Salemba Empat.

Peraturan Pemerintah nomor 1 tahun 2015 tentang perubahan atas peraturan pemerintah nomor 43 tahun 2014 tentang desa.

Rosmedi dan Risyanti, Riza. 2006.

Pemberdayaan Masyarakat.

Sumedang: Alqaprit

Jatinegoro.

Supriyono. 2010. Memahami

Penelitian Data. Jakarta:

Salemba Empat.

Widodo, Hartono. 2000. PAS

(Pedoman Akuntansi Syari'ah)

Panduan Praktis Operasional $B M T$. Bandung: Mizan.

Zaki Baridawan. 2009. Sistem

Akuntansi: Penyusunan

Prosedur dan Metode. Edisi

kelima. Yogyakarta: BPFE. 